\title{
Momentos iniciais da educação física em Goiás (1917-1929)
}

CDD. 20.ed. 796.09

796.5

\section{Resumo}

Este artigo analisa os momentos iniciais da organização institucional da educação física em escolas de Goiás, valendo-se de legislações, jornais, fotografias, livros de memórias e documentos oficiais como fontes. Desenvolvendo uma abordagem da história regional, o trabalho argumenta que o periodo entre 1917 e 1929 foi crucial para o início desse processo. Mais especificamente, uma combinação de interesses civis e militares, nacionais e regionais, de dentro e de fora de Goiás, parece ter sido o principal responsável por esse processo de construção social da educação física na região.

Palavras-chave: História; Memória; Esporte; Educação Física; Goiás.

\section{Introdução}

O objetivo desse artigo é analisar os momentos iniciais do oferecimento de atividades de ginásticas, esportes e exercícios físicos em instituiçóes escolares de Goiás. Resumidamente, podemos chamar essas práticas tấo somente de educação física, conforme expressão que passaria a designá-las no âmbito escolar ao longo do primeiro quartel do século XX. De acordo com resultados de minhas próprias pesquisas, que tem se debruçado sobre fontes diversas, abrangendo desde os meados do século XIX até meados do século seguinte, o período entre os anos de 1917 e 1929 corresponde às primeiras iniciativas sistemáticas em Goiás nesse sentido. Nessa época, reformas na organização do sistema de instrução pública goiano passaram a considerar muito seriamente a necessidade de uma "instrução física" para os seus estudantes.

\section{Método}

Do ponto de vista metodológico, a legislação do período apresenta-se como uma fonte importante. Uma série relativamente abundante de leis, decretos e regulamentos testemunham o desejo e o esforço de parte da elite política local em edificar dinâmicas educacionais sobre o corpo da população. Tal como apontaram Moreno e SEGANTINI ${ }^{1}$, documentações de natureza legal, sendo representaçóes que tentam legitimar determinados comportamentos em detrimento de outros, codificam valores desejáveis,
Em larga medida, foi por intermédio de açóes deflagradas no âmbito das escolas que a prática de diferentes tipos de exercícios físicos tornou-se, pouco a pouco, um hábito cotidiano em Goiás. Preocupaçôes com a educação, que diriam respeito também à educaçáo física, funcionaram mesmo como um dos principais elementos a favorecer o entusiasmo diante delas. No início, tratava-se de atividades difusas, pouco sistematizadas ainda, na maioria dos casos precárias, mas mesmo assim apreendidas já como importantes, às vezes indispensáveis. Com o tempo, contudo, elas ganhariam relevância crescente, adquirindo, inclusive, estatuto de um saber especializado no programa curricular das escolas de Goiás. Uma combinação de interesses civis e militares, nacionais e regionais, parece ter sido o principal responsável por esse processo. evidenciando, assim, as intençôes de grupos dominantes, mas também as formas de resistência de grupos subalternos. Segundo as autoras, que estudaram a educação do corpo em Belo Horizonte através desse tipo de documentação, "a legislação remete a diversos aspectos da vida social, relacionandose continuamente com os costumes de uma dada sociedade [...] a educaçáo do corpo nos espaços de sociabilidade do urbano realiza-se também, na e pela linguagem da lei" (p.75-9). Salvaguardando-se 
as devidas peculiaridades, conclusões assim podem se estender à Goiás também.

A esta série documental, acrescentem-se jornais, fotografias, livros de memórias, relatórios e outros documentos oficiais produzidos no âmbito de instituições mais diretamente relacionadas ao processo do qual tratamos aqui, isto é, escolas e órgãos militares. Uma análise articulada dessas fontes, à luz de esforços investigativos semelhantes realizados em outras regiôes do país ${ }^{2-5}$, pretende reconstituir, o mais detalhadamente possível, os motivos e as circunstâncias através das quais a educação física foi incorporada nas escolas goianas, ao mesmo tempo em que considera, por outro lado, os efeitos desse processo sobre o próprio modo de organização social dessa prática. A pesquisa documental realizou-se nos acervos da Biblioteca Nacional do Rio de Janeiro, do Arquivo Histórico Estadual de Goiás, do Instituto de Estudos e Pesquisas Históricas do Brasil Central, do Arquivo Frei Simão Dorvi, do Museu das Bandeiras e do Museu da Imagem e do Som de Goiás.

Teoricamente, o trabalho pretende uma abordagem da história regional. O desenvolvimento de estudos com ênfase em regióes específicas, tem a vantagem potencial de desafiar interpretaçóes generalistas, muitas vezes elaboradas a partir do estudo de grandes centros metropolitanos. Estudos regionais, nesse contexto, podem revelar a complexidade de variaçóes ou de regularidades possíveis no desenvolvimento histórico de fenômenos sociais. Isto não quer dizer, entretanto, que referências a outros contextos possam ou devam estar ausentes. Ao contrário, conforme formulara RAFAEL ${ }^{6}$, "o regional só aparece comparativamente: verticalmente, relacionado ao que procura mantê-la e incluía-a, como o Império, o Estado-Nação ou a Metrópole; e horizontalmente numa relação de complementaridade e conflito com outras regiôes" (p.1208). Nesse sentido, referências a acontecimentos desenrolados em outras regiōes interessaram também a este trabalho.

Esta pesquisa esteve preocupada com o processo de institucionalização da educação física em todo o Estado de Goiás. Documentaçôes disponíveis nos acervos pesquisados, porém, o permitem apenas em certa medida. Determinaçóes legais, por exemplo, tratavam e abrangiam quase sempre todo o Estado, na medida em que se ocupavam em tentar regular o funcionamento de escolas em geral. Estas documentaçôes, todavia, exibem mais as intençóes do que o que de fato aconteceu. Neste último espectro, notícias de jornais, de outro modo, permitem perceber melhor, parcialmente que seja, o funcionamento mais efetivo do cotidiano desta sociedade. O fazem, no entanto, com mais visibilidade aos acontecimentos da Cidade de Goiás, capital do Estado à época, em detrimento às cidades do interior. Em parte, esta situação é uma decorrência do próprio volume maior de publicaçôes organizadas ali, pois segundo cálculos de Arthur Neiva e Belisário Pena ${ }^{7}$, que viajaram por Goiás em princípios da década de 10, o Estado contabilizava, em 1912, oito jornais, dos quais quatro eram publicados na capital.

Para além desta dimensão quantitativa, a própria preservação documental de vestígios da vida social das cidades do interior goiano também dificulta as possibilidades de conhecimento mais detalhado desses contextos. Em primeiro lugar, há uma ausência quase absoluta de instituiçóes para salvaguarda das memórias locais; em segundo, a centralidade política exercida pela capital, que concentrava o aparato administrativo do Estado, responsável, em grande medida, pela produção, recepção e arquivamento de documentos oficiais, é outro aspecto importante a ser considerado nesse sentido.

Em que pese tais dificuldades, a reconstituição histórica do contexto dessas cidades interioranas é parcialmente possível. Jornais publicados dentro ou fora da capital, bem como documentos referentes à cidades do interior, mesmo que produzidos na capital, oferecem alguns indícios que permitem conhecer um pouco mais e melhor tais situaçóes. Assim, tanto quanto possível, este trabalho tentou exibir a manifestação de práticas de educação física em diferentes cidades do Estado, como é o caso de Pirenópolis, Itaberaí, Ipameri, Campininha, Rio Verde ou Bonfim, ainda que, pelos motivos citados, uma inevitável ênfase sobre situaçóes da capital seja notada.

Se o escopo geográfico do trabalho precisa considerar acontecimentos de outras regiốes que não àquela tomada como objeto de estudo, do ponto de vista cronológico, exige-se também a consideração de eventos de períodos imediatamente anteriores e posteriores àquele tomado como referência aqui (1917-1929). Só assim transformações históricas podem ser apreendidas como mudanças temporais entre um período e outro, singularizando as especificidades de cada época e explicando, em última instância, por que e sob que condiçóes um dado fenômeno social tornou-se diferente. 


\section{Resultados e discussão}

\section{Instrução militar}

A primeira tentativa em oferecer exercícios físicos regulares em escolas goianas deve-se aos militares. Em 1912, portaria do dia 23 de junho daquele ano, com base no artigo 237 do regulamento então vigente no Lyceu de Goyaz, que já atribuía ao diretor competência para providenciar instrução militar, determinava que os meninos matriculados entre a $3^{\circ}$ e a $6^{\circ}$ série comparecessem na escola as segundas e quintas-feiras, a partir das 17 horas, para receberem instrução militar ${ }^{8}$. A medida articulava-se claramente com iniciativas deflagradas pelo governo federal, que tentava, nessa época, expandir a instrução militar por escolas brasileiras.

Desde o século XIX, porém, notam-se esforços para integração de exercícios militares no sistema educacional brasileiro. Uma espécie de afinidade eletiva perpassaria ambas as atividades, apontadas, afinal, como instrumentos para reforma social, regeneração da nação e promoção do progresso-11. Desde essa época, instituições educacionais já eram apreendidas como espaços estratégicos para difusão de habilidades marciais por toda a população, o que incluía certo nível de preparação física. Na esteira dessa tradição, o decreto federal n. 6.947, de 8 de maio de 1908, aprovou o regulamento do alistamento militar obrigatório. Mais especificamente, o artigo 170 do regulamento federal do alistamento militar obrigatório, de 1908, estabelecia a instruçáo do tiro de guerra e as evoluçóes militares como obrigatórias para todos os alunos maiores de 16 anos $^{12}$. Em Goiás, entretanto, em que pese disposiçóes do regulamento de 1912 do Lyceu, não há evidências documentais de que a prática tenha se efetivado. Provavelmente, os alunos do Lyceu, única escola secundária para meninos em todo o Estado até 1929, esperariam alguns anos mais para praticar exercícios físicos como parte de suas atividades.

A própria obrigatoriedade do serviço militar, como um todo, não se efetivou na prática. Obstáculos culturais, com amplas camadas sociais avessas ao militarismo, além da visão das oligarquias rurais, que "não queriam perder seus peões", conforme apontou MACCANN ${ }^{13}$ (p.110), continuavam concorrendo para o seu fracasso. As mesmas dificuldades, porém, que impediam a realização prática da lei do serviço militar obrigatório, serviam também para mobilização e articulação de setores do Exército incomodados com a situaçáo. Diante das dificuldades, militares se voltavam cada vez mais para o assunto.
Entre o fim do século XIX e início do XX, federaçôes, linhas e sociedades de tiro foram criadas com a intenção de aproximar os jovens da elite ao serviço militar. A iniciativa, na verdade, materializava inquietaçôes de parte da elite militar brasileira, que se ressentia da distância entre as Forças Armadas e as classes dominantes. Nesse período, pessoas com renda anual superior a 100 mil contos de réis serviam à Guarda Nacional, enquanto àquelas com renda inferior a este valor eram recrutadas para o Exército. Militares acreditavam que tal situação comprometia a qualidade dos recursos humanos do Exército, o que os impelia a uma reforma dos modos de recrutamento. Assim, enfatizou-se a importância do serviço militar obrigatório, realizaram-se manobras como parte de exibiçóes públicas, ao mesmo tempo em que se reativou a ideia das sociedades de tiro para a aproximação do Exército com as elites civis. Em 1909, Sociedades de Tiro já mobilizavam 13.511 membros, em 50 instituiçóes espalhadas por todo Brasil, número que seria de $557 \mathrm{em} 1926^{14}$.

Depois da Primeira Guerra Mundial, fortaleceu-se ainda mais a percepção de que o civismo e o patriotismo eram sentimentos realmente importantes de serem fomentados entre a populaçáo, assim como o seu treinamento militar. Nessa época, jornais publicavam frequentemente artigos destacando a importância de instruçôes militares a todos os cidadáos. $\mathrm{O}$ jornal $\mathrm{O}$ Planalto, por exemplo, publicado em Santa Luzia, interior de Goiás, transcrevera artigo divulgado no jornal A Imprensa, do Rio de Janeiro, tratando das supostas pretensões militares dos alemães no Brasil. Nesse contexto, insuficiências com a educação militar dos brasileiros seriam um dos principais fatores de risco diante de uma eventual beligerância com outros países.

Que resistência poderemos opor à força hercúlea dos solados alemães? Nenhuma! No Brasil, infelizmente cada cidadão não é, como em outros países, um soldado. Nós cremos, inocentemente, na paz universal, mesmo com o que está se passando na Europa, onde mais se falou em paz! Embalados na rede dourada desta ilusão, não nos importamos com a instrução militar. No caso da invasão de nosso país, nem que sejamos patriotas, nada valerá a nossa boa vontade, por falta de instruçāo militar ${ }^{15}$.

Há tempos setores do Exército vinham alimentando discordâncias para com a orientação pacifista predominante em suas fileiras, sobretudo por causa da influência positivista, comprometida com a crença na paz universal. Quando o general Mallet assumiu 
o comando do Ministério da Guerra, em 1899, essas divergências ganharam corpo num conjunto de propostas de reforma, que forneceram as diretrizes para o Exército até a Primeira Guerra Mundial pelo menos. Grosso modo, as propostas de Mallet preconizavam mais atenção à disciplina e à instrução militar práti$\mathrm{ca}$, ao invés da orientação humanista que marcou a formação militar sob a influência positivista. Incapacidades militares na Guerra de Canudos, na crise do Acre e até mesmo na Revolta da Vacina, associadas a uma crescente sensaçáo de impotência diante de um mundo crescentemente militarizado, intensificavam essas demandas por reformas ${ }^{13}$.

A realização do programa de reformas prescritos por Mallet também dizia respeito a assimilação de técnicas e preceitos adotados pelas "naçôes mais adiantadas". Entre 1906 e 1910, três turmas de oficiais foram enviados para estágios junto ao Exército alemão, tido como exemplar por muitos militares brasileiros à época. Um dos resultados do estágio na Alemanha foi a formação de um grupo mais ou menos coeso ao redor do ideal de reforma e modernização do Exército brasileiro. Conhecidos desde entáo como jovens turcos, esses militares, influenciados pelas ideias do general Friederich Von Bernhardi, defendiam, entre outras coisas, o ensino da educação física para futuros recrutas antes mesmo de seus ingressos nas fileiras da corporação $^{16}$. De fato, ginástica e exercícios físicos tinham proeminência entre as preocupaçôes políticas do governo alemáo ao menos desde a década de 1840, quando os Ministros de Educaçãoo e da Guerra da Prússia, alarmados por problemas de saúde entre crianças e pelos temores decorrentes de instabilidades políticas na regiấo, começaram a apoiar a promoção de educação física nas escolas ${ }^{17}$.

Outro legado do estágio de militares brasileiros na Alemanha foi o início da associação ideológica entre reforma militar, reforma social e instituição do serviço militar obrigatório. Cada vez mais, parte da elite militar brasileira olhava para a reorganização do Exército como agente privilegiado na regeneração de toda a sociedade. Sob influência de ideais como as de Colmar von der Goltz, conselheiro alemão do Exército turco, acreditava-se que valores como a virilidade, a disciplina, o civismo e o fortalecimento físico do povo disseminar-se-iam mais e melhor através da "generalização do encargo militar"13 (p.132). O serviço militar obrigatório, portanto, tornava-se pedra de toque de um conjunto de reformas sociais e militares pretendidos por alguns setores do Exército no período.

A criaçáo da Liga da Defesa Nacional em 1916, com ampla campanha de Olavo Bilac em favor do serviço militar obrigatório, fortaleceu o consenso a respeito dessa importância ${ }^{14,16}$. Nessa época, aspiraçôes para uma educação militar mais generalizada começaram a ser efetivamente postas em prática, mas com dificuldades. Entre 1917 e 1929, estima-se que $78 \%$ dos jovens sorteados para o serviço militar foram dispensados ou simplesmente não se apresentaram ${ }^{13}$ (p.295). Interferências cada vez mais sistemáticas por parte dos militares sobre o sistema educacional foi um dos expedientes mobilizados para tentar contornar a situação. É sob tais circunstâncias que o sistema de instrução de Goiás se integrou às iniciativas desencadeadas no âmbito do governo federal.

Nessa época, provavelmente tentando atender demandas impostas pelo governo federal, o regulamento do Lyceu de 1917 (Decreto n. 4.470, de 20 de agosto), reiterava, em seu artigo 55, as "instruções expedidas pelo Ministério do Interior para execução do disposto no artigo 170 do regulamento anexo ao decreto n. 6.947, de 8 de maio de 1908", que tratava do alistamento e sorteio militar obrigatórios ${ }^{18}$ (p.2). Criava-se, assim, um Tiro de Guerra na Cidade de Goiás.

Formalmente, tratava-se tão somente do cumprimento das disposiçóes prescritas pelo regulamento do alistamento militar obrigatório de 1908. De acordo com o artigo 177 desse regulamento, estudantes obrigados a frequentar aulas de instrução militar deveriam fazê-lo com aproveitamento de pelo menos 60 exercícios de evoluçóes militares, além de 24 exercícios de tiro ao alvo com cartucho de guerra. Para o controle de frequência, depois de cada exercício, o instrutor responsável deveria registrar num livro rubricado pelo diretor do estabelecimento de ensino todas as ocorrências, bem como o nome dos alunos que faltaram. Ao final, com caráter avaliativo, um exercício de tiro de guerra e outro de evoluçóes militares, realizados diante de um inspetor, avaliariam o processo ${ }^{12}$.

$\mathrm{Na}$ prática, o ato significou que instruçóes militares seriam plenamente incorporadas à rotina do Lyceu. Já em 1918, 37 aulas de instrução militar seriam registradas ali. Dois anos depois, em 1920, esse número atingiria a proporção de 10 aulas por mês, denotando certo crescimento do espaço dedicado a essas práticas ${ }^{19}$. Desta feita, o inspetor fiscal do Lyceu, responsável por observar as condições de higiene, construção e asseio do edifício, anotou em seu relatório que as aulas de instrução militar eram as que tinham maior frequência nos momentos de suas visitas: 53 alunos $^{20}$. O relatório do presidente do Estado referente àquele ano, no mesmo sentido, destacou que a instrução militar 
teria sido "ministrada com muita regularidade"21 (p.32). Em 1924, aulas de instrução militar registravam-se já quase diariamente ${ }^{19}$. É bastante provável que tal situação também ocorresse em cidades do interior. Entre 1917 e 1925, relatórios do Ministro da Guerra registravam a existência de sete tiros de guerra em Goiás: em Catalão, Corumbá, Rio Verde, Bonfim, Pirenópolis, Santa Cruz, além da Cidade de Goiás (como exemplo da série, ver FARIA $^{22}$, anexo D). Fotografias de Ipameri da década de 30, dão testemunhos do funcionamento do Tiro de Guerra 323 (FIGURA 1). E a julgar pelo que sabemos a respeito do funcionamento dessas iniciativas, é perfeitamente possível que elas tenham intermediado a apresentação de práticas de exercícios a jovens da cidade.

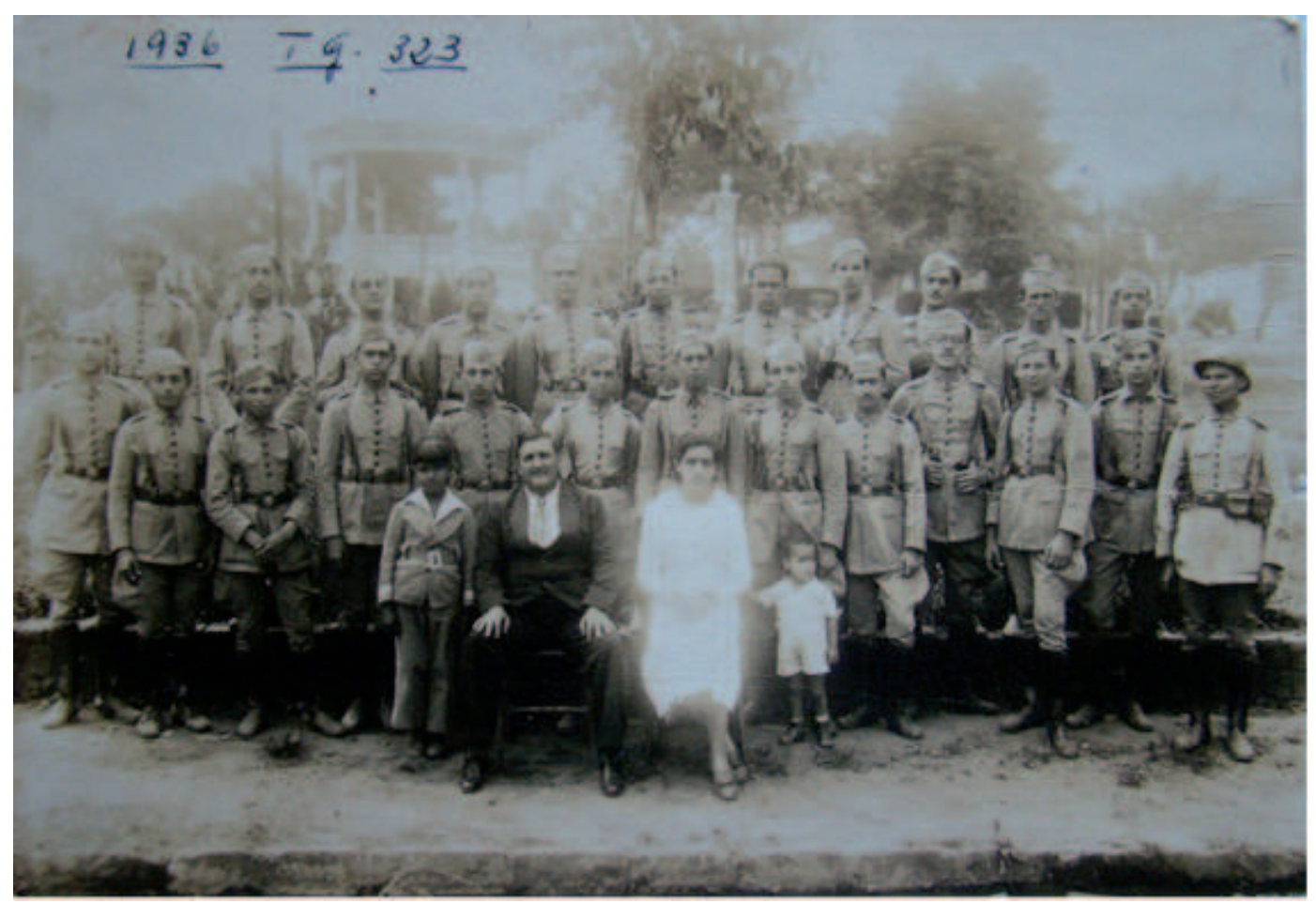

Fonte: Biblioteca Pública Municipal de Ipameri João Veiga. Autor Desconhecido. Sem data.

FIGURA 1 - Tiro de Guerra de Ipameri, em 1936.

Em Goiás, a cerimônia avaliativa ao final do período de instrução, realizada depois de 1917 sempre na presença de um inspetor de alta patente, constituía um espetáculo à parte. $\mathrm{O}$ evento seguia o receituário das celebraçóes escolares comuns à época: discursos, declamaçóes e presenças de autoridades $^{23}$. Segundo o relatório do presidente do Estado de 1922, naquele ano, "a entrega das cadernetas aos novos reservistas revestiu-se de grande solenidade, tendo comparecido ao ato o diretor, professores, autoridades civis e militares e distintas famílias" ${ }^{\prime 4}$ (p.11). Era este o momento em que uma comissão coordenava os exames dos alunos que receberam instrução militar ao longo do ano, aos quais entregavam, de acordo com os resultados, o certificado de reservista. Em dezembro de 1920, o ritual foi presidido pelo "distinto e brioso" Major Jovino Marques, que aprovou 17 alunos e reprovou outros seis ${ }^{25}$ (p.15). Com quase $75 \%$ dos alunos habilitados nos exames, João Alves de Castro ${ }^{21}$, presidente do Estado à época, avaliou o resultado como um "notável aproveitamento" (p.32).

Tais exames, segundo regulamento da diretoria geral do tiro de guerra, garantia aos aprovados o certificado de reservistas de segunda categoria ${ }^{16}$ (p.56). Mais que simplesmente habilitarem ou inabilitarem alunos, os exames também serviam para avaliar o trabalho dos instrutores, geralmente sargentos do Exército, no caso de Goiás. Em 1922, o presidente do Estado em exercício registrou em sua mensagem anual ao Congresso Legislativo elogios abertos ao instrutor do Lyceu naquele ano, o sargento Manuel dos Santos. Segundo ele, "de sua eficiência, deu testemunho, por ocasião da entrega de cadernetas de reservistas, o Sr. capitão Mario Barata, presidente da comissão examinadora, afirmando, que em confronto com os melhores alunos, aos do Lyceu de Goyaz, quanto à instrução militar, não cabe posição inferior"26 (p.53). 
As aulas de instrução militar em Goiás subordinavam-se a Inspetoria de Tiro de Guerra, sediada na 2a Região Militar, em São Paulo. Esta Inspetoria, em conformidade às orientaçôes do Ministério de Justiça e Negócios Interiores, estabelecia diretrizes para o funcionamento dos tiros de guerra em Goiás, além de prescrever um conjunto de obrigaçóes a serem observadas pelos instrutores: o conteúdo de cada aula deveria ser devidamente apontado no livro de registro de instrução; o responsável pela instrução militar deveria levar as cadernetas dos reservistas até a Inspetoria após os exames, onde um Capitão Inspetor as autenticava; a organização das atividades deveria ainda observar os quatro ramos da instrução militar, qual seja, tática, técnica, física e moral ${ }^{27}$.

Uma "instrução physica militar completa", a julgar pelos registros de Manuel dos Santos, instrutor militar do Lyceu em 1922, compreendia uma seção preparatória, uma seção propriamente dita, volta à calma e evoluçóes ${ }^{19}$ (fl.22). No que diz respeito à parte propriamente física da instrução, esgrima e três modalidades de "gymnastica" (aplicada, com e sem armas) eram os principais conteúdos. As instruçóes aconteciam às vezes pela manhã (das 6 às 9, das 7 às 9 ou das 7 às 10), às vezes pela tarde (geralmente entre 16 e 18 horas $)^{28}$. Pela manhá, segundo memórias do sargento Lindolpho dos $\mathrm{PAssos}^{27}$, geralmente realizavam-se aulas de instruçáo física no campo da Linha de Tiro do $6^{\circ}$ Batalhão de Caçadores, a dois quilômetros do centro da capital goiana. Segundo ele ainda, "instruçóes técnicas e táticas que se desdobravam em exercícios mais complexos eram ministradas em terrenos ou campos adaptáveis aos mesmos, a partir das dezesseis horas, as segundas, terças, quartas e sextas-feiras" (p.66). Às tardes de quinta-feira, de outra forma, seriam dedicadas às sessóes de tiro ao alvo.

Toda essa organização, na verdade, representava o cumprimento do "regulamento de instrucção physica militar", de âmbito federal e apresentado pelo decreto n. 14.784, de 27 de abril de 1921, que trazia indicaçóes precisas para o modo de execução dessas aulas, detalhando, inclusive, quais exercícios realizar, bem como quando e como fazê-los. O regulamento prescrevia, além dos "exercícios naturais", jogos que tornassem a instrução "mais simples e atraente". Segundo o regulamento, "jamais se deverá esquecer, com efeito, que a instrução physica, como a saúde que dela decorre, reclamam expansão e alegria. Toda monotonia provoca aborrecimento, isto é, fadiga nervosa, destruidora do moral e mais grave que a fadiga physica" 29 .

As diretrizes desse regulamento baseavam-se claramente nos métodos de educação física praticados pelo Exército francês, que desde 1919 colaborava com a formação e reorganização do Exército brasileiro através da chamada Missão Militar Francesa. A intensificação com preocupações sobre a educação física da população foi um dos legados dessa Missão. Em 1928, o major Pierre Ségur foi exclusivamente encarregado do assunto, ministrando aulas de educação física na Escola Militar de Realengo, cuja própria criação já fora resultado da cooperaçáo dos franceses ${ }^{30}$.

Desde a derrota na guerra com a Prússia, em 1870, o Exército francês tinha a ginástica e os exercícios em alta conta. Nessa época, esforços para integração formal da ginástica nas escolas francesas mantinha acentuada confusão entre exercícios físicos e exercícios militares ${ }^{31}$. O predomínio da ideologia da "nação em armas", que tomava as Forças Armadas como responsáveis pela formaçáo de cidadãos, somado a um nacionalismo belicoso, concorria para a situação. Nesse contexto, mais do que simples método de treinamento militar, a educação física era apreendida com propósitos de preparar corporalmente todos os cidadãos para a guerra. Em 1904, como consequência mais ou menos direta dessas experiências, uma comissão redigiu um Manual de Exercícios Físicos e Jogos Escolares para unificação dos métodos de ginástica em toda França. Depois da Primeira Guerra Mundial, em 1919 mais precisamente, novas diretrizes foram redigidas, tomando-se por base o Manual de $1904^{32}$. O chamado "Projeto de Regulamento Geral de Educação Física”, publicado em 1921 pelo Ministério da Guerra francês, foi depois integralmente adotado no Brasil através do "Regulamento Geral de Educação Física" (conhecido também como Regulamento $\mathrm{n}^{\circ}$ 7), que oficializou o "método francês" no ensino da educação física em escolas brasileiras.

Antes disso, porém, o regulamento de instrução física militar de 1921, como vimos, já trazia elementos que organizavam jogos e exercícios físicos em escolas durante as aulas de instrução física militar praticamente nos mesmos termos daqueles prescritos anos depois pelo Regulamento Geral de Educação Física (apresentado pelo Ministério da Guerra brasileiro em 1929 e formalizado em 1932), qual seja: racionalização do trabalho de ensino, adoção de parâmetros biológicos para organização das atividades, divisão dos alunos em grupos de idade e incorporação de jogos como recurso lúdico visando tornar mais atraentes e divertidas as aulas. Pode-se relativizar, dessa maneira, o entendimento corrente de que apenas no final da década de 20 a preocupaçáo dos militares brasileiros com o uso da 
educação física como instrumento de intervenção nas escolas se acentuaria (c.f. CASTRO ${ }^{30}$, p.91-2; Horta $^{16}$, p.69). Antes disso, como se vê no caso goiano, já se notava clara preocupação nesse sentido. A principal diferença é que até o fim da década de 20 , a realização prática de tais ambiçôes encontrava na instrução militar, e não nas aulas de educação

\section{Ginástica escolar}

Entre os meados da década de 10 e ao longo de toda década seguinte, intensificou-se, em Goiás, especialmente no interior de determinadas fraçóes das classes dirigentes, um processo de apropriação de argumentos em favor da ampliação do envolvimento do poder público com a oferta de serviços educacionais, processo que tem sido caracterizado no contexto nacional como "entusiasmo pela educaçáo"33. Em Goiás, tal como em outras regióes brasileiras, esse entusiasmo apareceu profundamente articulado a percepçóes sobre a necessidade de modernização. Jalles M. SiqueIrA ${ }^{34}$, por exemplo, afirmava que as estradas, isto é, "as vias de comunicação, por si sós, desenvolvem a educação popular" (p.5). Givace Machado ${ }^{35}$, por seu turno, afirmava, em sentido semelhante, que “ensinar é adestrar para a senda do progresso" (p.5).

Convicçóes como essa já orientavam o horizonte de ação de alguns políticos goianos ao menos desde os princípios do século XX, se não antes. Nessa época, José Xavier de Almeida, presidente de Goiás entre 1901 e 1905, foi um dos políticos que dedicou especial atenção ao assunto. Almeidi ${ }^{36}$ apontava para a instrução pública como "o assunto que reclama urgentemente os mais solícitos cuidados dos poderes estaduais" (p.28). Entre suas iniciativas sob este aspecto, registra-se a criação de uma Escola de Direito e a recriação da Escola Normal, em 1903, recebida com particular entusiasmo ${ }^{\text {. Segundo }}$ dizia-se à época, "o primeiro, o mais elementar dever dos governos é cuidar da educação e instrução desse povo" 37 . A Escola Normal, nesse sentido, responsabilizar-se-ia por aprimorar a formação de professores, afetando, em última instância, toda a educação de Goiás, conforme se acreditava. A expectativa geral era ver em prática "um método pedagógico moderno", inspirado em ensinamentos de educadores como Pestalozzi e Frabel; uma educação integral, preocupada com o fomento do desenvolvimento intelectual, mas sem descuidar também dos aspectos morais e físicos, constituíam física, o seu principal canal de realização. Mas a maneira pela qual tal intervenção se dava no âmbito das aulas de instrução militar ao longo de toda a década de 20, era fundamentalmente a mesma que aquela realizada na década seguinte através das aulas de educação física; inclusive no que diz respeito ao espaço privilegiado para tal atuação: a escola.

as principais prescrições para a nova Escola Normal. Segundo se dizia: "estamos certos de que, não desprezando a compreensão exata do aforismo que nos diz ser o homem uma inteligência servida por órgáos, o organizador da Escola Normal saberá aliar a ginastica escolar, o elemento robustecedor do corpo, aos exercícios do espírito, pois - Mens sana in corpore $\operatorname{sano"}^{37}$ (grifos no original).

Todavia, a realização de tais aspiraçóes continuaria a esbarrar em impedimentos de toda sorte, destacando-se os de caráter financeiro. Há tempos as contas do poder público estadual eram deficitárias. Apenas em meados da década de 10 um novo conjunto de circunstâncias viabilizaria uma economia estadual mais próspera, com efeitos diretos sobre a capacidade de atuação do aparelho burocrático sobre vários setores, inclusive o educacional. Nessa época, Goiás encontrava-se submerso num processo de profundas mudanças, "uma verdadeira revolução nos padróes de consumo e comportamento da população", conforme comentou Silva ${ }^{38}$ (p.97).

$\mathrm{O}$ estabelecimento de linhas férreas na região a partir de 1913 é apontado como um dos principais vetores dessas mudanças. Em 1920, Goiás já era o quarto maior produtor de arroz do Brasil, produzindo mais de 20 mil toneladas do produto por ano. $\mathrm{Na}$ mesma época, as importaçóes totais do Estado superavam a marca de 10 mil toneladas, enquanto as exportaçóes por meio da ferrovia, especificamente, ultrapassavam 12 mil toneladas ${ }^{39}$. Como consequência, em 1921, pela primeira vez em 150 anos, conforme registrou Paulo BerTran ${ }^{40}$, o Estado de Goiás não tinha dívidas. Sua arrecadação aumentou mais de 35\% entre 1917 e 1920 , passando de 1.944 contos em 1917, para 2.647 contos em 1920. O número de escolas "isoladas", reagindo, de certo modo, ao surto desenvolvimentista, saltou de 21 em 1917 , para 114 em 1920: aumento de mais de 500\%! O número de alunos matriculados, do mesmo modo, passava dos 918 em 1917, para 4.681 em 1920. 
Nesse contexto de intensas transformaçóes, o decreto número 4.089, de 23 de fevereiro de 1916, fixava alteraçóes no regulamento do Lyceu, visando adequá-lo ao regulamento do Ginásio Pedro II, dado que a "equiparação" era tida como algo de grande utilidade ${ }^{23, \mathrm{~b}}$. Entre as mudanças propugnadas por esse decreto, destaca-se a inclusão de aulas de ginástica para todos os quatro anos daquele estabelecimento de ensino, bem como a designaçáo de um professor para ministrá-las ${ }^{41}$. Tentando viabilizar esse programa, ofício número 4.092, de 26 de fevereiro de 1916, nomeava Francisco Mondino como professor de ginástica do Lyceu ${ }^{42}$. A rigor, esta foi a primeira vez que um professor fora contratado especialmente para cuidar da educação física dos alunos numa escola goiana. A partir de abril daquele ano, a ginástica passaria a constar dos programas de exames da instituição, ao lado do português, francês, latim, geografia e desenho. Nessa época, o Lyceu teria já alguns materiais de ginástica, pois em julho de 1916, Vicente Pedotella recebera $300 \$ 000$ por materiais fornecidos para essas aulas ${ }^{43}$.

Apesar disso, não havia ainda uma formação especializada nesse sentido, como de resto, em nenhuma outra cadeira do ensino secundárioc. Entre 1913 e 1915, Francisco Mondino, antes de ser nomeado professor de ginástica, lecionou aulas de diferentes assuntos, nomeadamente português, italiano, história universal e história do Brasil ${ }^{44-46}$. Nesse período, Mondino também aparece como funcionário da Escola de Aprendizes Artífices de Goiás (criada em 1910), em função que não foi possível precisar até agora. Mesmo depois de nomeado professor de ginástica do Lyceu, substituiu ainda o professor de psicologia e lógica que naquele instante, por sua vez, lecionava aulas de geografia geral, elementos de cosmografia e geografia do Brasil ${ }^{47}$. Quando da sua exoneraçáo do cargo, em abril de 1917, por solicitaçáo dele próprio, Mondino aparece como professor de ginástica e caligrafia do Lyceu e também da Escola Normal, que funcionavam no mesmo prédio esta época ${ }^{48}$.

Desta feita, a ginástica parece já ter se consolidado como prática pedagógica regular, com um lugar claramente estabelecido no organograma dessas duas instituiçóes, o Lyceu e a Escola Normal, que dispunham, então, de uma "cadeira de gymnastica". Nesse contexto, Donizetti Martins de Araújo, exaluno do Lyceu entre 1907 e $1912^{49-52}$ foi indicado para substituir interinamente Francisco Mondino na condução dessas aulas ${ }^{53}$. Donizetti parece ter permanecido no exercício dessa função até 1920, quando recebia 2:799\$996, tal como os professores de desenho e inglês; um pouco mais que um professor primário, que recebia 2:040\$000; mas menos da metade que um professor de matemática e francês, cujos salários eram de 6:159\$984, um dos maiores entre os empregados do Estado à época ${ }^{54}$. Para se dimensionar o poder de compra desses valores, citese que a assinatura anual do jornal Correio Official custava $12 \$ 000$ nessa época.

A eventual saída de Donizetti do cargo de professor de ginástica não parece ter comprometido o desenvolvimento dessas atividades, pois em 1922, anúncios com os horários das atividades do Lyceu já previam, além do desenho, aritmética, álgebra, geografia, português, latim, francês, alemão, física, química, filosofia e historia universal, "aulas de gymnastica”, praticada três vezes por semana, em sessóes de 50 minutos, para as turmas do primeiro ao terceiro ano ${ }^{55}$. No ano seguinte, a ginástica se estenderia também às turmas do quarto $\mathrm{ano}^{56}$. A consolidação institucional da nova prática no Lyceu parece mesmo inequívoca nessa época.

No que diz respeito ao ensino primário, já a partir de 1915 se notavam esforços para organizar o sistema de educação pública do Estado em outros termos. Nessa época, aviso de Francisco de Borja Mandacarú, secretário de instrução, indústrias, terras e obras públicas, "a bem do aproveitamento das crianças que frequentam as escolas primárias do estado", segundo os termos do próprio aviso, fixava novos horários para o funcionamento dessas instituiçóes em Goiás. De acordo com a nova determinação, as aulas, dali em diante, deveriam realizar-se entre às 9 e às 15 horas, com intervalo de uma hora a partir do meio-dia. Esse período de intervalo, segundo o aviso, deveria ser preenchido com merenda e recreio. Segundo se lê:

$\mathrm{O}$ espaço das 12 às 1 horas será destinado à merenda e ao recreio, durante o qual, obedecendo aos preceitos de higiene pedagógica, os professores entreterão com os alunos, jogos ou brinquedos apropriados à idade, ao sexo, ao meio e ao fim a que se destina uma escola primária, devendo ter em vista especialmente a formação do caráter das crianças, auxiliando assim os pais ou corrigindo os defeitos adquiridos na educação doméstica ${ }^{57}$.

Em meados do ano seguinte, a lei número 527, de 7 de julho de 1916, que reorganizava a instruçáo primária de Goiás, entre outras providências, tentava criar um grupo escolar na capital para crianças de sete a 14 anos, dirigida pelo mesmo diretor da Escola Normal e funcionando em anexo a ela. Com a reforma, o ensino seria divido em três anos, prevendo leitura, escrita da língua materna, aritmética, 
noçôes de geografia geral, geografia do Brasil (e especialmente de Goiás), noçôes de geometria, desenho linear, "lições de cousas", noçôes de higiene, instrução moral e cívica, noçôes de ciências físicas e naturais, trabalhos manuais, além de música, canto, ginástica e exercícios militares ${ }^{58}$ (p.2). É a primeira vez que o ensino da ginástica aparece numa proposta curricular para o ensino primário de Goiás. A iniciativa seria reconhecida pelo nome de Curso Anexo da Escola Normal, que com outros nomes e de forma sutilmente diferente, isto é, fora dos modernos parâmetros dos grupos escolares, existia desde $1904^{23,59}$.

Em todo o Brasil, a criação e implantação dos grupos escolares representou uma inovação arquitetônica, metodológica e organizacional para o ensino primário. Em oposição às chamadas "escolas isoladas", também conhecidas como unitárias, singulares, reunidas ou agrupadas, cujo modelo era a reuniâo de vários alunos, de diferentes idades e níveis de aprendizado, sob os cuidados de um mesmo professor, numa única sala, os grupos escolares fundamentavam-se nos princípios da seriação, da racionalidade técnica e da divisão e hierarquização do trabalho pedagógico. Nesse novo modelo, os alunos, reunidos em um único e grande prédio, que envolvia o trabalho simultâneo de vários professores, deveriam ser classificados, separados e distribuídos de acordo com um sistema de avaliaçáo por idades e classes de ensino ${ }^{60-61}$. Além da racionalização e maior empenho no controle dos tempos pedagógicos, os grupos escolares também representaram, do ponto de vista político, uma oportunidade de propaganda das realizaçóes do poder púbico no campo educacional, "uma espécie de vitrine da modernização", conforme expressão de Souza ${ }^{62}$ (p.278-82).

Em Goiás, todavia, tais intençôes não se realizaram na tentativa de 1916. Apenas dois anos depois, em 1918, parte das ideias apresentadas ali ganharia vida prática. A lei número 631, conhecida como reforma João Alves de Castro e Americano do Brasil, bem como o decreto número 5.930, daquele mesmo ano, que regulamentava o ensino primário no Estado, aprofundou o processo de reorganizaçáo desse nível de ensino em Goiás, reformando a educação de todo o Estado e instaurando, segundo PINTo ${ }^{63}$, "a forma escolar moderna na realidade goiana” (p.230). Inspirada nas reformas educacionais de Sáo Paulo e do Rio de Janeiro, a reforma goiana incorporava e ampliava a abrangência de elementos caracterizados como tipicamente modernos, tais como uma grade fixa de horários, exames públicos, cantos, ginástica e recreios. No ano seguinte, em 1919, finalmente entrou em funcionamento na capital o primeiro grupo escolar do Estado, "instituiçáo símbolo da modernidade pedagógica", de acordo ainda com PinTo $^{63}$ (p.230). Mais que isso, seguindo a autora, estabeleceu-se, nessa época, intenso debate político sobre a necessidade e o valor da educaçáo para o progresso de Goiás. Segundo ela:

No período de domínio caiadista (1917-1930), ocorreu o crescimento de uma rede de escolas públicas de todos os níveis educacionais e a adoção de políticas públicas reguladoras da formação de professores, dos programas e métodos de ensino, dos tempos e espaços escolares, dos livros didáticos, da obrigatoriedade escolar, das modalidades e modelos de escola etc. PINTo ${ }^{63}$ (p.229)d.

Em 1921, o governo estadual autorizaria a criação de outros quatro grupos escolares. Até 1924, instituiçôes desse tipo estariam em funcionamento na capital, Rio Verde, Santa Luzia, Bonfim (atualmente Silvânia) e Curralinho (atualmente Itaberaí). Até 1930 contar-se-iam 16 grupos escolares em todo o Estado $^{23}$ (p.512), alguns avaliados muito positivamente. Sobre o de Bonfim, por exemplo, dizia-se que era "o mais moderno e sem dúvida o melhor que o Estado possui" "64 (p.65).

Exercícios físicos, em geral, compunham parte desse novo programa educacional. A nova organização legal do ensino primário goiano definia, em seu artigo 18, "[que] a parte physica do ensino primário será essencialmente prática e se destinará ao desenvolvimento orgânico da criança; constará, para o sexo masculino, de exercícios gerais de ginásticas, militares e de canto; para o sexo feminino, de ginástica orgânica e de cantos" ${ }^{\prime 65}$. O texto era reiterado no decreto número 5.930 , de 24 de outubro de 1918, regulamentando o ensino primário, em que a educação moral e cívica, a educação intelectual e a educação física eram definidas como objetos da educação primária ${ }^{66}$. Além disso, a ginástica também deveria fazer parte dos programas das festas em comemoração à bandeira, ao aniversário da fundaçáo do grupo escolar, ao aniversário da cidade onde funcionava o grupo, ao início e encerramento dos trabalhos letivos, bem como à distribuição dos certificados, ao lado de atividades de poesia, cantos e hinos escolares ${ }^{67}$. 
Fonte: Museu da Imagem e do Som de Goiás. Autor Desconhecido. Sem data.

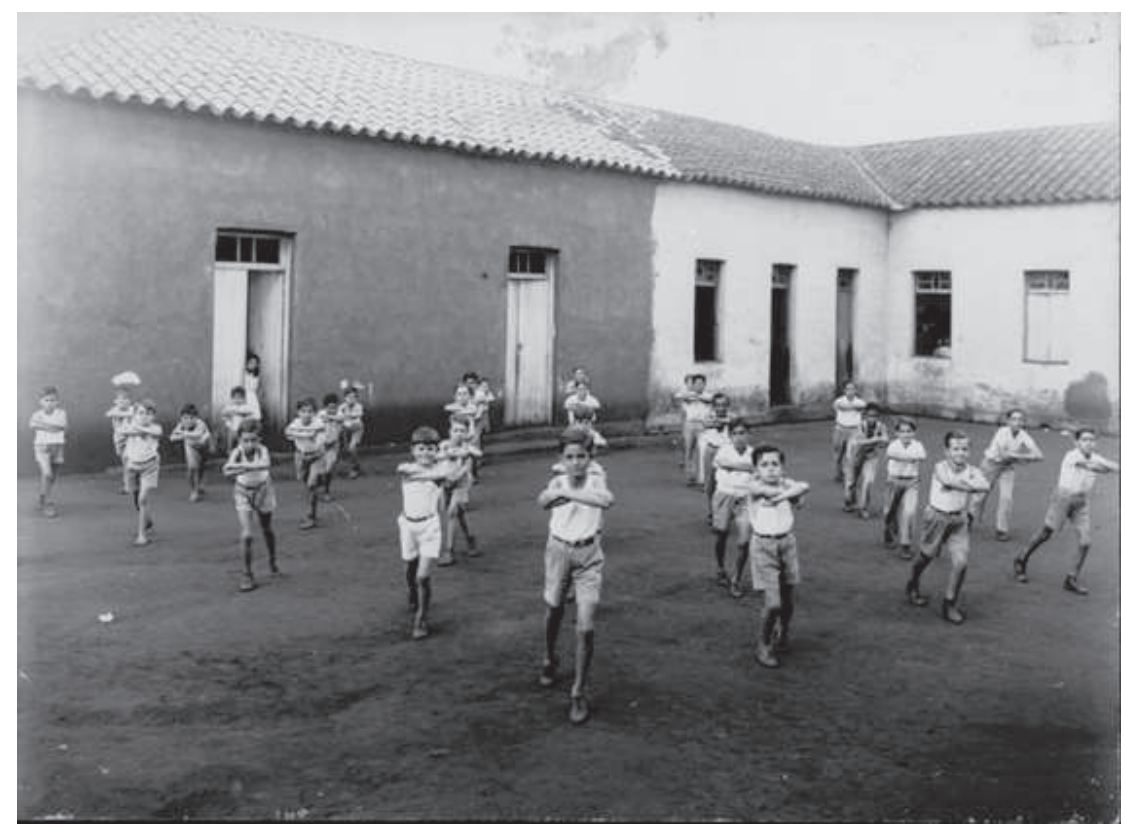

FIGURA 2 - Alunos praticando ginástica em Rio Verde na década de 40.

Evidenciando de maneira ainda mais explícita as afinidades entre os novos planos para as instituiçóes escolares primárias e os exercícios físicos em Goiás no período, o regulamento dos grupos escolares de 1925 prescrevia-nos como parte obrigatória das atividades. Para as turmas do terceiro e do quarto ano, especificamente, além de reproduzir-se o programa para as turmas do primeiro e do segundo ano, que dizia respeito a ginástica respiratória, marchas, evoluçóes, danças cadenciadas, movimentos metódicos e ordenados em forma, além de corridas com arcos, de velocidade e resistência, havia já os "jogos ao ar livre", o "volley-ball" e o "basket-ball"68.

Nada disso, contudo, significa que tais atividades foram efetiva e prontamente incorporadas ao cotidiano das escolas primárias. Relatório de Rodolpho da Luz Vieira, juiz de direito em Ipameri, referente ao ano de 1920, tratou de algumas limitaçóes que afetavam instituições de ensino primário em Goiás naquele momento. De modo geral, dizia Vieira, as escolas de Ipameri pareciam-lhe "mais ou menos em ordem, havendo por parte das crianças algum aproveitamento". A escola do sexo feminino, entretanto, apesar de bem localizada, no centro da cidade, pareceu-lhe ter "acomodaçóes acanhadas e sem pátio para o necessário recreio das alunas". Como alternativa, o juiz sugeria a criação de grupos escolares, supondo, provavelmente, que este modo de organização garantiria melhores condiçōes ${ }^{69}$.

Na prática, contudo, o funcionamento de grupos escolares poderia ser táo precário quanto qualquer outro estabelecimento de ensino. O relatório referente ao ano de 1926 de Ofélia Sócrates do $\mathrm{NASCIMENTO}^{70}$, diretora do grupo escolar da capital na ocasião, fizera uma avaliação bastante crítica a respeito das condiçóes de funcionamento desse estabelecimento. Em suas palavras:

$\mathrm{O}$ prédio em que atualmente está instalado o Grupo Escolar da Capital, não se presta absolutamente para isso. Suas salas são muito pequenas, sem ar suficiente e com péssima iluminação. Basta dizer que o cômodo que funciona o $1^{\circ}$ ano, o maior da casa, mal comporta 30 crianças, é completamente escuro, apesar de ter muitas telhas de vidro, e não tem, para ventilá-lo, uma única janela que dê para o exterior do prédio. A privada, única que há, é contrária a todas as regras de higiene. Para piorar a situação, vêm as contínuas goteiras, os desmoronamentos quase intermitentes dos muros, os enormes rasgōes produzidos no forro por goteiras mais parecidas bicas, dando-lhe o aspecto de tapera e ruína. Não há no grupo uma única sala que, em dias de festa, comporta todos os alunos ${ }^{70}$ (p.3).

O relatório, na verdade, é apenas a síntese de insatisfaçôes que se manifestaram ao longo de todo aquele ano. Nesse período, Ofélia importunou as autoridades o quanto pode, inundando lhes os gabinetes com ofícios que solicitavam lâmpadas, reformas, pinturas, materiais, pagamentos em atraso e toda uma série de reivindicaçóes visando melhorias das instalações daquele grupo escolar ${ }^{71}$. Nesse espírito, o 
relatório da diretora destaca também que as aulas de ginástica, previstas no programa de ensino das escolas primárias, não se realizavam por pura inadequação do espaço. Segundo ela, "o quintal, excessivamente plantado, não oferece o menor espaço onde se possa dar aula de ginástica, parte do programa completamente abandonado por esse motivo" ${ }^{\prime 70}$ (p.3).

Mesmo assim, uma disseminação mais efetiva dessas práticas por escolas primárias e secundárias de Goiás parece ter se processado, se não cotidianamente, ao menos em datas comemorativas. Em 1922, o programa das comemoraçóes pelo centenário da independência na capital goiana, apesar de modesto, conforme se divulgou, realizou, às 17 horas do quarto dia de atividades, "jogo disportivo [sic] e evoluçóes militares pelos atiradores do Lyceu"72. Interessante notar que o simples fato de envolver jogos e exercícios físicos, mesmo em atividades realizadas fora do âmbito das aulas de instrução militar, parecia incentivar a presença de militares, o que reforça a importância da participação desse grupo na organizaçáo de atividades ligadas à educação física nas escolas de Goiás. Em verdade, atividades das aulas de ginástica e de instruçáo militar por vezes se justapunham. Em muitas situaçôes, militares e civis compartilhavam, afinal, métodos, espaços e materiais de ensino, além de convicçóes a respeito do valor, da funçáo e da importância do ensino da educação física em escolas. Por ocasião do centenário da independência, foi Manuel dos Santos, responsável pela instrução militar no Lyceu, quem organizou tanto a demonstraçáo de manejo de armas, quanto os "jogos atléticos". Segundo notícia do jornal A Imprensa, "graças a competência e ao afinco com que o sargento Manuel dos Santos preparou os estudantes do Lyceu, mostraram-se estes inexcedíveis no manejo das armas e nos jogos atléticos que se realizaram no largo do chafariz"73.

Ao longo da década de 20, a programação de algumas festas de escolas primárias contaria com exibiçôes de ginástica e sobretudo atividades esportivas cada vez mais frequentemente. Em 1929, por exemplo, as atividades realizadas por ocasiāo da Proclamação da República daquele ano, no pátio do Grupo Escolar da capital, que teve lição de instrução física, corrida de estafetas, corrida de ovos, ginástica, corrida das agulhas, quebra-pote, cabo de guerra, salto em altura e salto em largura, envolvendo alunos e alunas do Grupo Escolar da Capital, do Grupo Escolar Estadual, do Grupo Escolar Dr. Agenor de Castro, do Grupo Escolar Municipal, da Escola Normal e do Tiro de Guerra $78^{74, \mathrm{e}}$.

Paulatinamente, assim, o espaço dedicado às atividades físicas parece ter crescido nas escolas goianas. Em 1926, por iniciativa de um grupo de padres salesianos, inaugurou-se na cidade de Bonfim (atualmente Silvânia), o Ginásio Anchieta. Não se tem notícias sobre o funcionamento da escola em seus momentos iniciais. Mas é certo que a partir do início dos anos 1930, esta escola atribuiria uma importância ao menos relativa às práticas esportivas. Dessa época em diante, seria frequente o seu envolvimento na participaçáo ou mesmo realizaçáo de disputas esportivas diversas ${ }^{75-76}$. Fotografias dessa época dão testemunho desse envolvimento (FIGURA 3).

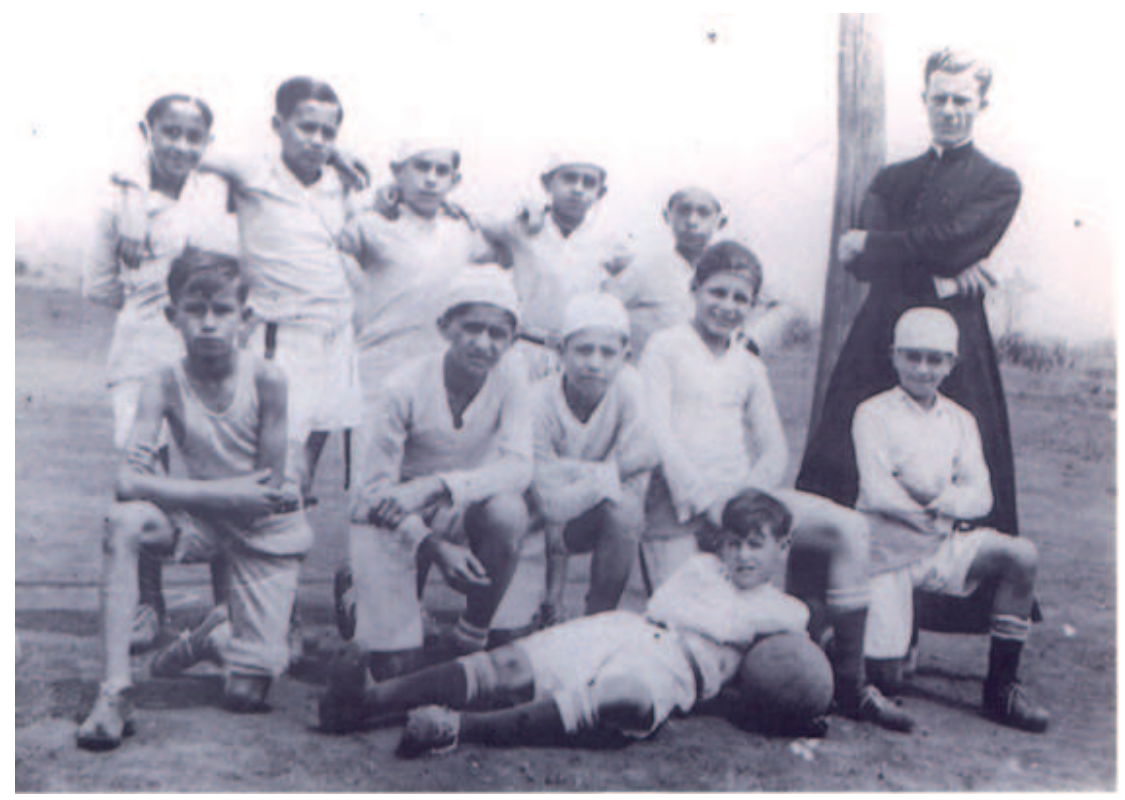

Fonte: Instituto de Estudos e Pesquisas Históricas do Brasil Central. Fundo Carlos Campos, atividades extraclasse. Autor Desconhecido. Sem Data.

FIGURA 3 - Time de futebol do Ginásio Anchieta, no início dos anos 30. 
De maneira semelhante, o Colégio São João, inaugurado em 1928 na cidade de Pirenópolis, contava, desde o início, segundo noticiava-se, com um prédio higiênico, com vastos e arejados cômodos, além de confortáveis pátios para jogos esportivos ${ }^{77}$. $\mathrm{Na}$ capital, o quadro de horários do grupo escolar já registrava, em 1930, "ginástica", "ginástica respiratória" e "jogos ginásticos", de acordo com a série, no que supostamente poderia ser também observado nos grupos escolares do interior ${ }^{78}$.

Nessa época, o governo goiano, "interessado em uniformizar os métodos de ensino", moldá-los em conformidade à moderna prática da pedagogia, observando o que se fazia "nos centros mais adiantados do país", obteve cooperação do governo de São Paulo, que enviou um grupo de três professores "bastante experimentados nas lides escolares" ${ }^{\text {" }}$. Esta iniciativa representava, na verdade, a concretização de um antigo projeto acalentado fazia mais de uma década por parte da elite política de Goiás. Desde meados dos anos 10, alguns políticos locais viam no sistema de educação pública de São Paulo um verdadeiro modelo a ser seguido, especialmente no que diz respeito à formação de professores, já identificado, neste momento, como um dos principais obstáculos ao desenvolvimento educacional de Goiás. Em 1914, Olegário Pinto ${ }^{80}$, presidente do Estado, comentou o assunto em seu relatório anual ao Congresso Legislativo. Em suas palavras: Conhecendo as necessidades que temos de formar bons professores, telegrafei para São Paulo, onde o ensino tem atingido a um elevado grau de perfeição, a exemplo de outros Estados, pedindo para ser contratato um professor competente para pôr em prática as reformas que julgo indispensáveis à marcha regular do ensino. Infelizmente não foi possível, até agora, realizar esse contrato que julgo imprescindível a uma proveitosa reforma, sem o que todo o regulamento permanecerá letra morta ${ }^{80}$ (p.23).

Náo por acaso, 15 anos depois, quando finalmente realizou-se a antiga ambição de obter ajuda e cooperação do governo paulista, uma das primeiras recomendações da chamada Missão Pedagógica Paulista, foi justamente a criaçáo de um curso de aperfeiçoamento para professores. Cumprindo parte das recomendações formuladas por essa Missão Pedagógica, iniciaram-se as atividades da "escola de ginástica pedagógica" para as alunas da Escola Normal, facultada às professoras do Grupo Escolar, com aulas todas as terças e quintas-feiras, a partir das $14^{81}$. Paralelamente, outras Escolas Normais do Estado, não oficiais, mas equiparadas, também começaram a registrar aulas de ginástica em seus currículos, como foi o caso do Colégio Santa Clara, em Campininha, região onde mais tarde, em 1937, seria criada a nova capital do Estado: Goiânia ${ }^{82}$.

Esses acontecimentos marcam o término de um período de formação inicial de atividades de educação física em escolas goianas. Na década de 30, a educaçáo física já apareceria como atividade consolidada em escolas goianas, além de assumir um conteúdo sutilmente diferente, com crescente presença de práticas esportivas, ao invés da marcante presença da ginástica. A popularidade crescente de esportes, aliás, provavelmente concorreu para esta consolidação institucional, ao mesmo tempo em que a incorporação de tais atividades na rotina de escolas, parece também ter favorecido seu reconhecimento público mais geral. Conforme anotou LinHALES ${ }^{83}$, se a escola contribuiu para a difusão da prática cotidiana de esportes e exercícios, essas práticas também contribuíram para a realização de um programa político que tinha na escolarizaçáo um de seus motes privilegiados.

O início da organização da educação física em Goiás foi resultado da combinação de duas forças sociais paralelas e simultâneas, que coincidiram e às vezes até se justapuseram, embora não necessariamente se confundissem. De um lado, esforços de políticos locais, comprometidos com ideais modernizadores e preocupados em fazer de Goiás uma região nacionalmente reconhecida, favoreceu a intensificação de esforços na disseminação da educação escolar, bem como a incorporação de pedagogias tidas como modernas à época, sempre elogiadas por serem adotadas "nos centros mais desenvolvidos", como se dizia, o que incluía também ginásticas e outras formas de exercícios, como os jogos e os esportes.

Em meados da década de 20, insatisfaçôes com relação ao monopólio do poder político exercido por grupos da capital começaram a se manifestar, especialmente no Sul e Sudoeste do Estado, cujo desenvolvimento econômico mais agudo parecia animar o diagnóstico de que as vantagens decorrentes da produção de riquezas distribuíam-se assimetricamente entre as regiōes que as produziam. Uma progressiva dissidência política organizar-se-ia a partir daí. Crescentemente, grupos de oposição passariam a identificar no establishment uma oligarquia retrógrada. Reinvindicações relacionadas ao desenvolvimento de instituiçóes educacionais, culturais ou recreativas por vezes seriam veículos 
nesse sentido. Em 1928, por exemplo, jornais de Itaberaí publicavam queixas a respeito da concentração exclusiva do ensino secundário na capital. No plano recreativo, jornais de oposição apontavam a ausência de equipes goianas de futebol nos campeonatos brasileiros de seleçóes estaduais (realizados a partir de 1922) como mais um símbolo do ostracismo que estaria afetando Goiás ${ }^{84}$. Atividades de educação física, simbolicamente ligadas a um ideal de progresso e modernidade, eram mesmo manipuladas politicamente como parte de estratégias para um programa de reforma mais amplo.

De outro lado, setores interessados em ampliar a influência e o raio de ação de um aparelho burocrático centralizado, se empenhavam em reformar os mecanismos de recrutamento e treinamento militar. Parte de tais intençóes realizar-se-ia por intermédio da inclusão de aulas de instrução militar em escolas por todo o Brasil, como foi o caso do Lyceu de Goyaz, que registrou atividades desse tipo desde 1917. O modo de organizaçáo pedagógico prescrito e adotado por essas práticas, no fim, extrapolou suas próprias fronteiras, influenciando, em larga medida, o ulterior desenvolvimento da educação física, mesmo quando formalmente desvinculada das atividades de instrução militar. Assim, o encontro de mudanças deflagradas, a um só tempo, de dentro e de fora de Goiás, parece ter sido o principal responsável pelo início da organização institucional da educação física em Goiás até 1929.

Depois disso, outros traços gerais parecem ter caracterizado a educação física na região. Além de sua consolidaçáo e crescimento no espaço institucional de escolas, houve também uma transição entre o predomínio de atividades de ginástica como componente das aulas de educação física, em direção a um crescente predomínio do esporte, em fenômeno análogo ao que tem sido caracterizado em outras regiốes ${ }^{3,85}$. Nas escolas de Goiás, a promoçáa de esportes também se tornaria cada vez mais frequente a partir de 1930. Competiçóes esportivas entre escolas tornar-se-iam lugares-comuns; instalaçôes de escolas e outras instituiçôes educacionais, como o Jardim de Infância, a Faculdade de Direito ou de Farmácia, serviriam para reuniōes, assembleias ou outras atividades de clubes esportivos, como bailes e festas carnavalescas (como exemplo, ver BrasiL Central Atletico Clube ${ }^{86}$; em 1934, alunos do Lyceu criariam uma "associação intelectual e esportiva" ${ }^{87}$, que meses depois começaria a participar de competiçóes esportivas diversas ${ }^{75}$; artigos tratando da importância pedagógica da educação física passaram a ser publicados nos jornais de Goiás com relativa frequência (ver Maia ${ }^{88}$; PAssos $^{89}$; Artiaga $^{90}$ ).

Tudo isso marca um novo período de transição para os sentidos da educação física em instituições escolares de Goiás. Daí em diante, um envolvimento intensivo e crescente de diferentes setores da sociedade civil com esses temas concorreria de maneira definitiva para sua consolidaçáo. Esse desenvolvimento, porém, estaria relacionado, se náo bastante condicionado, ao anterior período de formação histórica dessas práticas, que este trabalho, em suma, tentou reconstituir. Sintomaticamente, o desenvolvimento esportivo em Goiás na década de 30 guardaria laços de ligação explícitos com acontecimentos da década anterior. Alguns dos seus mais ativos e ativas protagonistas seriam mesmo alunos e alunas de escolas goianas em algum momento da década anterior, onde puderam aprender a nova prática em aulas de ginástica ou de instrução militar, que tinham já nos esportes um de seus componentes de ensino, como vimos. Foi este o caso, por exemplo, de José Nicolau SADDI, conhecido nas rodas esportivas como "um dos grandes propugnadores do esporte", "um esforçado sportista goyano" 11 . Nicolau Saddi, como outros de sua geração, fora aluno do Lyceu, onde frequentara tanto as aulas de instrução militar quanto as de ginástica, conforme se sabe através das listas de aprovados dos exames da escola ${ }^{92}$. Determinar com precisão o quanto tais experiências influenciaram, de fato, a disposiçẫo para o posterior envolvimento com esportes é difícil, talvez impossível. De todo modo, trata-se de uma hipótese bastante provável, dada a importância social e simbólica que instituiçóes escolares desempenhavam na vida social de Goiás daquele período.

\section{Notas}

a. A Escola Normal Pública foi criada em Goiás em 1858, alternando-se, desde então, em sucessivos períodos de reformas e ostracismo até os princípios do século $\mathrm{XX}^{59}$.

b. Desde o Império, a legislação educacional brasileira estabelecia a realização dos chamados "preparatórios" ou "exames parcelados", avaliaçóes que pretendiam verificar a cultura e a capacidade intelectual de alunos interessados em ingressar 
nos cursos superiores de então: Medicina, Direito e Engenharia3 ${ }^{93}$ Em 1901, já sob o regime republicano, a Reforma Epitácio Pessoa alterou essa ordenação, criando o "sistema de equiparação". De acordo com este, escolas que se organizassem em conformidade aos currículos do Ginásio Nacional (Colégio Pedro II), no Rio de Janeiro, tido como modelo, teriam o direito de emitir diplomas válidos para o ingresso no curso superior, garantindo aos seus egressos dispensa de quaisquer avaliaçôes adicionais. Muitas elites estaduais interessaram-se pela equiparação. Era a única maneira de adiar a ida de seus filhos para outras cidades, onde realizariam os cursos preparatórios para ingresso nos cursos superiores ${ }^{33}$. Em Goiás, especificamente, relatório do Secretário de Instrução, Indústria, Terras e Obras Públicas de 1905, recomendava ao presidente do Estado que após a solução de alguns problemas de organização e funcionamento do Lyceu, "toda a nossa atenção deve convergir para obtermos a sua equiparação ao Gymnasio Nacional"94 (p.8).

c. Em 1929, transcorrido mais de uma década de preocupaçóes sistemáticas com a formação profissional de professores, havia 232 professores em Goiás, dos quais mais de 75\% (176) eram leigos ${ }^{95}$ (p.116).

d. Segundo Canezin e Loureiro ${ }^{59}$, confirmando esse entendimento, "na década de 20 evidenciou-se a procura pela educação escolar, fato este correlacionado com a forma de desenvolvimento econômico e político do Estado [...] Estas transformaçóes e o crescimento do aparelho burocrático do Estado fizeram aumentar a procura pela educação escolar, o que levou os sucessivos governos caiadistas a ampliarem os investimentos em educação no período de 1919 a 1930” (p.58-9).

e. Excetuando-se aulas de ginástica na Escola Normal, ministradas desde 1917, essas "festas esportivas", como eram chamadas, constituíram uma das primeiras oportunidades para a participação das mulheres na prática de esportes em Goiás. Por ocasião das comemoraçôes do dia Pan-Americano, por exemplo, depois dos discursos, cantos de modinha e recitação de poesias, seguiu-se a realização de corridas de estafeta, corrida de 100 metros e jogos de bola ao cesto, entre as alunas da Escola Complementar e da Escola Normal. Segundo notícia da época, "numerosas pessoas da nossa alta sociedade assistiram ás festas não podendo esconder a excelente impressão que lhes ficou dos conhecimentos esportivos das alunas" .

\section{Abstract}

The early of physical education in Goiás (1917-1929)

This article analyze the early periods of institutional organization of the physical education in schools at Goiás, using laws, newspapers, photographs, books of memories, and official reports as resources. Developing a regional history approach, the work states that the years between 1917 and 1929 was very important for starting this process. More specifically, a combination of civil and military, national and regional interests, from inner and outside of Goiás, was the main responsible for this process of social building of physical education in the region.

KEY WORDS: History; Memory; Sports; Physical education; Goiás.

\section{Referências}

1. Moreno A, Segantini VC. Educação do corpo na e pela linguagem da Lei: potencialidades da legislação como fonte. Pensar Prát. 2008;11:00.

2. Bombassaro T, Vaz AF. Sobre a formação de professores para a disciplina educação física em Santa Catarina (1930-1940): ciência, controle e ludicidade na educação dos corpos. Educar. 2009;33:111-28.

3. Vago TM. Histórias da educação física. Belo Horizonte: Mazza; 2010.

4. Moreno A, Segantini VC, Fernandes GÁ, Jesus LJ. "Gesticulação nobre, sympathica e attitude digna”: educação do corpo na formação de professoras (Escola Normal Modelo da Capital, Belo Horizonte, 1906-1930). Rev Bras Hist Educ. 2012;12:221-42.

5. Schneider O, Bruschi M, Ferreira Neto A. Educação física e escolarização na Revista de Educação do Espírito Santo (1934-1937). Movimento. 2012;18:219-235.

108 • Rev Bras Educ Fís Esporte, (São Paulo) 2014 Jan-Mar; 28(1):95-111 
6. Rafael VL. Regionalism, area studies, and the accidentes of agency. Am Hist Rev. 1999;104:1208-20.

7. Neiva A, Pena B. Viagem cientifica pelo norte da Bahia, sudoeste de Pernambuco, sul do Piauí e de norte a sul de Goiás. Brasília: Senado Federal; 1999.

8. Portaria. Correio Official, Goyaz, 4 jul. 1912;63:3.

9. Souza RF. A militarização da infância: expressões do nacionalismo na cultura brasileira. Cad Cedes. 2000;20:104-21.

10. Nascimento AO. As evoluçóes militares no ensino primário em Minas Gerais no início do século XX. In: Fonseca TNLE, Veiga CG, organizadores. História da educação: temas e problemas. Belo Horizonte: Mazza; 2011. p.217-39.

11. Silva CLB, Melo VA. Fabricando o soldado, forjando o cidadão: o doutor Eduardo Augusto Pereira de Abreu, a Guerra do Paraguai e a educação física no Brasil. História, Ciências, Saúde. 2011;18:337-53.

12. Brasil. Decreto n. 6.947, de 8 de maio de 1908. [citado 11 nov. 2012]. Disponível em: http://www2.camara.leg.br/ legin/fed/decret/1900-1909/decreto-6947-8-maio-1908-511501-publicacaooriginal-1-pe.html.

13. MacCann FD. Soldados da pátria: história do Exército brasileiro, 1889-1937. São Paulo: Companhia das Letras; 2007.

14. Carvalho JM. As forças armadas na Primeira República. In: Fausto B, organizador. História geral da civilização brasileira.São Paulo: Difel; 1978. t.3, v.2, p.181-234.

15. As pretensóes germânicas no Brasil. O Planalto, Santa Luzia, 10 jul. 1915;185:2.

16. Horta JSB. O hino, o sermáo e a ordem do dia: regime autoritário e a educação no Brasil (1930-1945). 2a ed. Campinas: Autores Associadores; 2012.

17. Naul R. History of sport and physical education in Germany, 1800-1945. In: Naul R, Hardman K, editors. Sport and physical education in Germany. New York: Routledge; 2002. p.15-27.

18. Regulamento do Lyceu de Goyaz. Correio Official, Goyaz, 20 ago. 1917;131:1-5.

19. Museu das Bandeiras. Fundo referente ao Lyceu de Goyaz. Instrucção militar. Goyaz; s.d. v.141. [manuscrito].

20. Museu das Bandeiras. Fundo referente ao Lyceu de Goyaz. Visitas do Inspetor Fiscal. Goyaz; s.d. v.138. [manuscrito].

21. Castro JA. Mensagem presidencial enviada ao Congresso Legislativo do Estado. Goyaz: Typographia do Correio Official; 1921.

22. Faria JC. Relatorio apresentado ao Presidente da Republica dos Estados Unidos do Brazil pelo Marechal Graduado José Caetano de Faria, Ministro de Estado da Guerra em maio de 1918. Rio de Janeiro: Imprensa Militar, 1918. [anexo D].

23. Bretas GF. História da Instruçẫo Pública de Goiás. Goiânia: Cegraf/UFG; 1991.

24. Jardim ER. Mensagem ao Congresso Legislativo do Estado de Goyaz. Goyaz: Typographia do Correio Official; 1922.

25. Major Jovino Marques. Correio Official, Goyaz, 18 dez. 1920;302:10.

26. Lima MR. Mensagem apresentada ao Congresso Legislativo do Estado de Goyaz, na abertura da $3^{\circ}$ sessão ordinária da $9^{\circ}$ legislatura, a 13 de maio de 1923, pelo coronel Miguel da Rocha Lima, 2º vice-presidente em exercício. Goyaz: Typographia do Correio Official; 1922.

27. Passos LS. Goiás de ontem: memórias militares e políticas. Goiânia: Norton de Camargo Passos; 1986.

28. Museu das Bandeiras. Fundo referente ao Lyceu de Goyaz. Instrucção. Goyaz; s.d. v.142. [manuscrito].

29. Brasil. Decreto n.14.784, de 27 de abril de 1921. [citado 11 nov. 2012]. Disponível em: http://www2.camara.leg.br/ legin/fed/decret/1920-1929/decreto-14784-27-abril-1921-511224-publicacaooriginal-1-pe.html.

30. Castro C. Exército e nação: estudos sobre a história do exército brasileiro. Rio de Janeiro: FGV; 2012.

31. Arnal T. La aparición de la gimnasia em la educación de lós jóvenes franceses: el Gimnasio Civil de Grenelle como lugar de experimentación de uma pedagogia nueva (1820-1833). In: Scharagrodsky P, compilador. La invención del "homo gymnasticus": fragmentos históricos sobre la educación de los cuerpos em movimiento em Occidente. Buenos Aires: Prometeo Libros; 2011. p.53-75.

32. Terret T, Saint-Martin J. Journey in the historiography of the French method of physical education: a matter of nationalism, imperialism and gender. Hist Educ. 2012;41:713-32.

33. Nagle J. Educação e sociedade na Primeira República. São Paulo: EDUSP; 1974.

34. Siqueiras JM. Governar é construir estradas ou educar o povo. Correio Official, Goyaz, 23 nov. 1929;1632:5-6.

35. Machado G. Pela instrucção. Correio Official, Goyaz, 16 nov. 1929;1630:5.

36. Almeida JX. Mensagem enviada ao Congresso na abertura da segunda sessão da quarta legislatura pelo presidente do Estado Dr. José Xavier de Almeida. Goyaz: Typographia do Goyaz; 1902.

37. Napoleão A. A Eschola Normal. Goyaz, Goyaz, 6 mar. 1903;755:3.

38. Silva AL. A revolução de 30 em Goiás. 2a ed. Goiânia: Cânone; 2005.

39. Borges BG. O despertar dos dormentes. Goiânia: UFG; 1990.

40. Bertran P. Formação econômica de Goiás. Goiânia: Oriente; 1978.

41. Decreto n.4089, de 23 de fevereiro de 1916. Correio Official, Goyaz, 26 fev. 1916:57:1. 
42. Officios. Correio Official, Goyaz, 2 abr. 1916;62:3.

43. Officios. Correio Official, Goyaz, 8 jul. 1916;74:4.

44. Secretaria do Interior, Justiça e Segurança Pública. Correio Official, Goyaz, 28 jun. 1913;107:3.

45. Administração do Exm. Sr. Dr. Olegario Herculano da Silveira Pinto. Correio Official, Goyaz, 8 nov. 1913;124:2.

46. Administração do Exmo. Sr. Dr. Salathiel de Lima. Correio Official, Goyaz, 13 mar. 1915;10:1.

47. Secretaria de Instrucção, Industrias, Terras e Obras Públicas. Correio Official, Goyaz, 23 set. 1916;85:2.

48. Secretaria de Instrucção, Industrias, Terras e Obras Públicas. Correio Official, Goyaz, 14 abr. 1917;112:3.

49. Editaes. Semanario Official, Goyaz, 13 dez. 1907;409:4.

50. Editaes. Semanario Official, Goyaz, 7 dez. 1909;488:5.

51. Exames do Lyceu. Correio Official, Goyaz, 17 nov. 1911;38:4.

52. Exames do Lyceu. Correio Official, Goyaz, 7 nov. 1912;79:3.

53. Actos do Governo. Correio Official, Goyaz, 21 abr. 1917;113:1.

54. Relaçáo dos Empregados do Estado na Capital, aptos para serem jurados, de accordo com a Lei Judiciária vigente. Correio Official, Goyaz, 28 fev. 1920;261:8.

55. Lyceu de Goyaz. Correio Official, Goyaz, 28 mar. 1922;589:3.

56. Lyceu de Goyaz. Correio Official, Goyaz, 27 mar. 1923;728:2.

57. Aviso n. 3. Correio Official, Goyaz, 23 dez. 1915;50:4.

58. Actos do Governo. Correio Official, Goyaz, 28 out. 1916;90:1-2.

59. Canezin MT, Loureiro WN. A escola normal em Goiás. Goiânia: UFG; 1994.

60. Souza RF, Faria Filho LM. A contribuição dos estudos sobre grupos escolares para a renovação da história do ensino primário no Brasil. In: Vidal DG, organizador. Grupos escolares: cultura escolar primária e escolarização da infância no Brasil (1893-1971). Campinas: Mercado de Letras; 2006. p.21-56.

61. Schueler AFM, Magaldi AMBM. Educação escolar na Primeira República: memória, história e perspectivas de pesquisa. Tempo. 2009;13:32-55.

62. Souza RF. Os grupos escolares e a história do ensino primário na Primeira República: questôes para um debate. Rev Educ Públ. 2008;17:273-84.

63. Pinto RMN. Caminhos cruzados: a cidade e a escola na história da educação em Goiás na primeira república. In: Barra VML, organizador. Estudos de história da educação de Goiás (1830-1930). Goiânia: PUC-GO; 2011. p.217-38.

64 A informação goyana: Revista Mensal, illustrada e informativa das possibilidades econômicas do Brasil Central. Rio de Janeiro, 15 jan. 1920;4.

65. Actos do Poder legislativo. Correio Official, Goyaz, 7 set. 1918;186:1.

66. Decreto n. 5930, de 24 de outubro de 1918. Correio Official, Goyaz, 26 out. 1918;193:1.

67. Decreto n. 5930, de 24 de outubro de 1918. Correio Official, Goyaz, 9 nov. 1918;195:2.

68. Regulamento e programa de ensino dos grupos escolares do Estado de Goyaz. Correio Official, Goyaz, 7 mar. 1925;996:3.

69. Juiz de Direito de Ipamery. Correio Official, Goyaz, 28 fev. 1921;352:3-4.

70. Nascimento OS. Relatório apresentado ao Exmo. Sr. Dr. Secretário do Interior e Justiça, 1926. Goiás; 1926. [Mimeo. Arquivo Histórico Estadual de Goiás. Documentos avulsos I. Caixa 737].

71. Arquivo Histórico Estadual de Goiás. Documentos avulsos I. Goiás. [Diretoria do Lyceu, caixa 737].

72. Centenário da independência. Correio Official, Goyaz, 29 ago. 1922:649:3.

73. As festas do centenário. A Imprensa, Goyaz, 16 set. 1922;30:1-2.

74. 15 de Novembro. Correio Official, Goyaz, 12 nov. 1929;1628:6.

75. Secção Esportiva. Correio Official, Goyaz, 30 de maio de 1934;2759:8.

76. Caravana intelectual esportiva. Correio Official, Goyaz, 18 jun. 1935;3032:4.

77. Collegio S. João. Voz do Povo, Goyaz, 27 jul. 1928;68:3.

78. Horarios adoptados no Grupo Escolar da Capital e que podem ser também observados com as devidas modificaçóes do tempo nos Grupos do Interior. Correio Official, Goyaz, 1 abr. 1930;1682:4-5.

79. Instrucção Pública. Correio Official, Goyaz, 24 out. 1929;1621:6.

80. Pinto OH. Mensagem apresentada ao Congresso Legislativo do Estado de Goyaz, pelo Dr. Olegário H. da Silveira Pinto, em 13 de maio de 1914. Rio de Janeiro: Papelaria Mendes; 1914.

81. Instrucção Pública. Correio Official, 6 mar. 1930;1672:5.

82. Menezes ÁC. O Colégio Santa Clara e sua influência educacional em Goiás. Goiânia: O Popular; 1981.

83. Linhales MA. A escola e o esporte: uma história de práticas culturais. São Paulo: Cortez; 2009. 
84. Dias C. Primórdios do futebol em Goiás, 1907-1936. Rev Hist Reg. 2013;18:31-61.

85. Schneider O. Entre a correção e a eficiência: mutaçôes no significado da educação física nas décadas de 1930 e 1940 - um estudo a partir da Revista Educação Physica. Rev Bras Ci Esporte. 2004;25:39-54.

86. Brasil Central Atletico Clube. Correio Official, Goyaz, 22 dez. 1931;2084:8.

87. Associação intelectual e esportiva. Correio Official, Goyaz, 25 abr. 1934;2730:1.

88. Maia W. Exercícios physicos e athleticos. O Aspirante, Goyaz, 31 mar. 1931:4.

89. Passos LS. Educação física. Voz do Povo, Goyaz, 1 mai. 1932;232:2.

90. Artiaga G. Educação física: elementos fisiológicos. Correio Official, Goyaz, 18 fev. 1934;2679:3.

91. José Nicolau Saddi. Cidade de Goyaz, Goyaz, 25 jun. 1939:49:1.

92. Mensagem Presidencial. Correio Official, Goyaz, 31 mai. 1930:1702:18.

93. Haidar MLM. O ensino secundário no Império Brasileiro. São Paulo: EDUSP; 1972.

94. Castro JA. Relatório apresentado ao Dr. J. Xavier de Almedida, presidente do Estado de Goyaz, pelo bacharel J. Alves de Castro, secretario de Instrucção, Industria, Terras e Obras Públicas, em 21 de abril de 1905. Goyaz: Typographia Perseverança de Pacífico Marques Aranha; 1905.

95. Ferreira JC. Presidentes e governadores de Goiás. Goiânia: UFG; 1980.

96. Dia Pan Americano. Correio Official, Goyaz, 16 abr. 1931;1887:2.

\section{Agradecimentos}

Este estudo contou com apoio financeiro do CNPq.

Agradeço aos funcionários da Biblioteca Nacional do Rio de Janeiro, do Arquivo Histórico Estadual de Goiás, do Instituto de Estudos e Pesquisas Históricas do Brasil Central, do Arquivo Frei Simão Dorvi, do Museu das Bandeiras e do Museu da Imagem e do Som de Goiás pelo suporte durante a pesquisa.

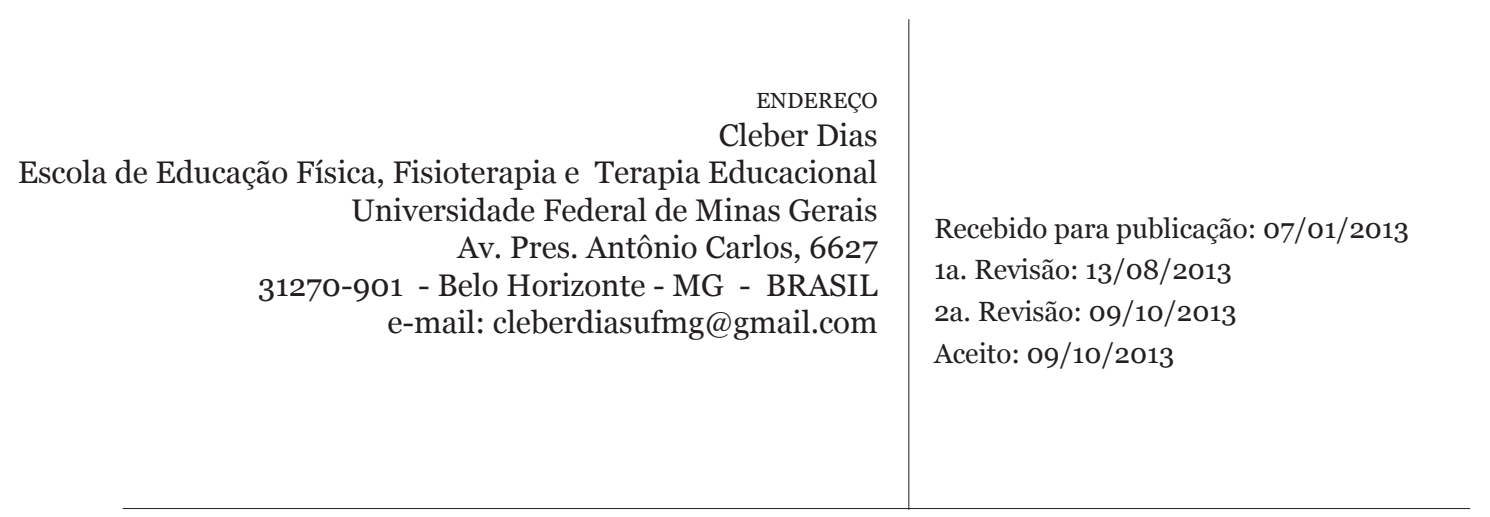

Rev Bras Educ Fís Esporte, (São Paulo) 2014 Jan-Mar; 28(1):95-111 • 111 